\title{
The Development of Collaborative Jig Saw Project- Based Learning Model to Improve Students' Learning Outcomes in Thermodynamics on Vocational College
}

\author{
Arwizet Kaharudin ${ }^{1}$, Nizwardi Jalinus ${ }^{2}$, Ambiyar $^{3}$, Remon Lapisa ${ }^{4}$ \\ Department of Mechanical Engineering ${ }^{1,2,3}$ \\ Department of Automotive Engineering ${ }^{4}$ \\ Universitas Negeri Padang \\ Padang, Indonesia \\ ambiyar@yahoo.com
}

\begin{abstract}
This paper describes the development steps of The Collaborative Jig Saw Project-Based Learning (CJPjBL) Model in thermodynamics on vocational college. The development of the CJPjBL model applies five steps of the ADDIE model ie: 1) analyzing current thermodynamics learning model, 2) designing the new learning model, 3) developing model and internal validation, 4) implementing CJPjBL model, and 5) comparing achievement of students learning outcomes using CJPjBL model to conventional model. The product of this research was the results of a learning model with nine syntaxes in thermodynamics through validity, practicality and effectiveness test. Expert validity test results on the construction and content of the CJPJBL model with Aiken $V$ were 0.863 and 0.84 . The practicality test results by lecturers and students were 83,67 and 80,94 in very practical category. The results of effectiveness test through t-test on student learning outcomes using CJPjBL and conventional model showed significant differences. The means value of student learning outcomes using the CJPjBL and conventional models at the end of the lecture were 88.28 and 74.80. In conclusion, this study showed that the CJPjBL model was valid, highly practical and more effectively used in thermodynamics' course in vocational college.
\end{abstract}

Keywords - Vocational college, CJPjBL, validity, practical, effectiveness, conventional model

\section{INTRODUCTION}

Education is a conscious and well-planned effort to create an atmosphere of learning and learning process so that learners actively develop the potential within themselves to have religious spiritual power, self-control, personality, intelligence, noble character, as well as the skills required for him, society, nation and country [1]. Education is any effort planned to influence other people, individuals, groups or communities so that they do what the educational offender expects [2].

An educational process is considered qualified if the learning process is practical, effective, and innovative. This learning process will provide learners with meaningful learning experiences [3]. In the process of meaningful education, learners are more active, constructive, intentional, authentic and cooperative while being supported by human resources, facilities, quality and adequate infrastructure.
The learning process in the education unit should be interactive, inspirational, fun, challenging, motivating students to participate actively, and providing sufficient space for initiative, creativity and independence according to students' physical and psychological talents, interests and development [4]. The learning process is one component of an important educational situation. Therefore, the learning process should be carried out with the best careful planning and measurable. It is intended to realize the results of quality education, not least in vocational education. Vocational education is that parts of education which makes an individual more employable in one group of occupation than in another [5].

From the educational institution's perspective, vocational education teaches people how to work effectively. Vocational education takes place when an individual or a group of individuals gets information, understanding, abilities, skills, appreciation, interests and / or attitudes, which enable him to start or continue a productive activity [6].

Vocational Education is one of the most powerful instruments for enabling all members of the community to face new challenges and to find their roles as productive members of society. It is an effective tool for achieving social cohesion, integration and self-esteem. Vocational education as "organized educational program" which is related to the preparation of individuals for paid or unpaid employment, or for additional preparation for a career requirement [6]. In addition, [6] stated that Vocational education is concerned about the training potential of the labor force. It covers any forms of education, training, or retraining designed to prepare people to enter or to continue in employment in a recognized occupation. From the above description, it can be concluded that vocational education is education that prepares students to enter the world of work. Widely, vocational education is defined as an activity that develops each person's potential according to his or her talents and skills. Development of self-potential based on knowledge and skill to survive and work according to field of expertise or able to open own business.

The 21 st century was often referred to as the era of globalization. In this era, vocational education graduates are required to be able to change in the environment and rapid 
technological developments in the industry to remain exist and excel. This condition makes the vocational education is oriented to the development of skills and application of literacy skill development as well as strengthening character education [7].

Changes and technological advances make the structure of the type of work in the industrial world also changed. Various types of work require new competencies as well, so that industrial production with new technologies can be economically valuable to the nation and country [7]. Graduates of vocational education are required to have adaptive, innovative and applicative competencies in the world of work. In addition, [7] mentioned the development of 21 st century technology demands human enter the transition era, human ability change will leave the ability of manual (manual skills) to the ability of brain (brain skills). Whatever the type of work and profession available, all require thinking skills.

Graduates of vocational education in this era of globalization are required to think critically, creatively, innovatively, be able work together and communicate with the environment. To produce qualified graduates, vocational education must use various models in the learning process which should be able to adapt to changes and technological advances that develop in the industrial world [8].

The use of appropriate learning models will provide good social skills and high motivation for students. The learning process needs to pay attention to the cultivation of soft skills aspects, among others: cooperation, mutual respect, sense of belonging, sense of responsibility, honesty and willingness to sacrifice. Nowadays, all this feels neglected and still has not gained much attention in educational institutions, as well as in vocational education institutions. Educational institutions vying only to teach cognitive knowledge in order to pursue good value, as students graduate from the institution[9].

The development of learning model in vocational education should be done by vocational education managers so that the competence of graduates is in line with the demands of the world of work. Higher work competitions as technology advances and workplace dynamics demand that vocational education institutions are able to cope with and anticipate changes which take advantage of existing resources, create creative, innovative and adaptive learning situations in accordance with the objectives of vocational education [10].

\section{A. Thermodynamics' Course in Vocational College}

Thermodynamics was one of the subjects that must be given to the students of Mechanical Engineering Diploma Program, Faculty of Engineering, State University of Padang. Mechanical Engineering Diploma Program in Engineering Faculty, State University of Padang is one of Vocational College in Padang City.

Based on the data of students' learning outcomes and observations conducted to the students taking thermodynamics on Mechanical Engineering Diploma Program, Engineering Faculty, State University of Padang, it was found that most of the students felt that it was difficult to understand thermodynamics course well. Whereas, the implementation of thermodynamics course was often and mostly found in the industrial world like: steam power plants, propulsion and gas power plants, hydro power plants, geothermal power plants, pump installations and piping systems, internal and external combustion engines, fluids' engines, geothermal power plants, heat exchanger and so on.

To understand the concepts and principles in thermodynamics, it requires the ability of high level thinking of the students since this course is very abstract and difficult to understand This is what makes the students difficult to master the subject of thermodynamics quickly, turning something abstract into real conditions in the field.

Thermodynamics is one of the basic subjects of expertise that must be understood and mastered by students in the Mechanical Engineering Diploma Program on vocational college. Thermodynamics is a course that examines energy, transforms energy, and analyzes these changes and can apply them to energy conversion machines in the industrial world [11]. Considering its relation to energy, almost all activities of human life related to energy. Thermodynamics is an important subject to be mastered by the students of Mechanical Engineering Diploma Program, Engineering of Faculty, considering that the implementation of the subjects of thermodynamics course is very much found in industry such as in energy conversion machines such as: PLTA, PLTU, PLTG, Earth (PLTPB), Pump Installation and Piping System, Heat Excahenger System, Propulsion System, Fuel Motor, Fluid Engines, Refrigeration and Air Conditioning ( $\mathrm{R}$ \& A), and so forth. The result of observation and need analysis showed that most students find it difficult to master the material of thermodynamic teaching well. Weak work competence as they work later in the world of work/industrial.

\section{B. Learning Model and Collaborative Jig Saw Project- Based Learning Model (CJPjBL) in Thermodyanamics}

Learning model is a reference used by lecturers in delivering teaching materials. A learning-model instructional materials including books, films, tapes, and computermediated programs and curriculum (long term courses of study) [12]. Learning model is a plan or a tutorial setting and to shape instructional materials-including books, films, tapes, and computer-mediated programs and curriculum (long term courses of study). Collaborative Jig Saw Project-Based Learning (CJPJBL) is a learning model in which a combination between a collaborative learning model and a project-based learning model [13].

Collaborative Jig Saw Project-Based Learning (CJPjBL) is a learning model that can provide reinforcement on cognitive and affective aspects for the learners. The CJPjBL model is a combination of a collaborative learning model with a project-based learning model. The application of learning model is by combining several precise methods that can be the solution of the problems that occur. One of the effective learning methods to facilitate students in mastering the material was the collaborative learning model. Collaborative Jig Saw learning (CJ) affords students enormous advantages not available from more traditional instructions because a group - whether it be the whole class or a learning group within the class - can accomplish any meaningful learning and solve problems than any individual can do alone [13] [17]. While project-based learning (PjBL) is well suited to help students to be active learners because it conditions their learning for real learning [14]. 
The model of project-based learning (PjBL) is a constructivist pedagogy that intends to bring about in-depth learning for learners to use an inquiry. Therefore, $\mathrm{PjBL}$ is well-suited to help students become active learners. PjBL helps students to see that learning and life take place in contexts that effect the kind of solutions that are available and possible. The use of the CPJBL model involves students in an active, collaborative, student-centered learning process that develop the challenges of life and careers in today's increasingly complex environment [18].

Looking at the advantages of $\mathrm{CJ}$ model and PjBL above model, CJPjBL is suitable to be used in thermodynamics learning. The CJ model strengthen student cognition by studying in groups, while PJBL model will train students to think critically to find solutions.

\section{METHODS}

\section{A. The Development of CJPjBL Model in Thermodynamics} Following Instructional Design of ADDIE Model

The development of collaborative jig saw project-based learning (CJPjBL) in thermodynamics follows the step of developing instructional design of ADDIE Model that consists of five stages: analysis, design, development, implementation, and evaluation [15]. Various flavors and versions of ADDIE model exist. During analysis, the designer identified learning problems, the goals and objectives, the audiences' need, existing knowledge, and any other relevant characteristics. The analysis also considered learning environment, any constraints, delivery options, and timeline for the project. The principle in this stage is collecting all potentials and problems that exist because the research basically started from those potential and problem. Design is a systematic process of specifying learning objectives. Detailed storyboards and prototype are often made, and the look and feel, graphic design, user-interface and content are usually determined in this stage. This design stage is a joint stage between product design and design validation.

Next, development is the actual creation (production) of the content and learning materials based on the design stage [15]. The development steps include activities to create, purchase, and modify teaching materials. Those steps include selecting activities, determining methods, media and appropriate learning strategies to be used in conveying the materials or substance of the program. Implementation is delivery of learning materials to students. During implementation, the plan is put into action and a procedure for training the learner and teacher is developed. Materials are delivered or distributed to the student group. After delivery, the effectiveness of the training materials is evaluated.

Evaluation stage consists of formative and summative evaluation. Formative evaluation presents in each stage of the ADDIE process. Summative evaluation consists of the tests designed for criterion-related references items and providing opportunities for feedback from users. Revisions are made as necessary.

One of the learning design functions of ADDIE model is to be a guide in building the tools and infrastructure of effective, dynamic training programs and supporting the performance of the training itself. The design of the learning model of ADDIE is logical, profound and comprehensive and can be evaluated at every stage [15].

\section{B. The Design of ADDIE Model}

The structure chart of instructional design of ADDIE model development can be illustrated as shown in Figure 1.

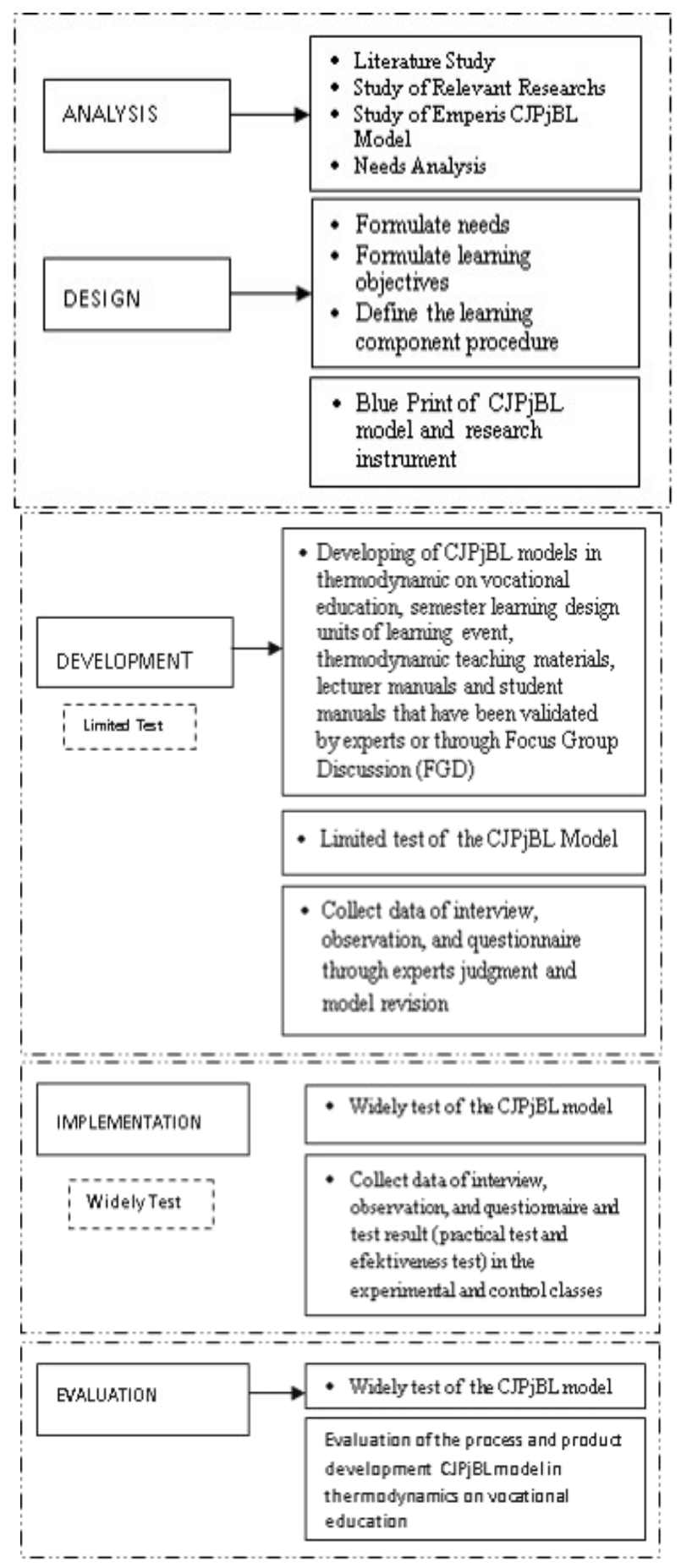

Fig. 1. Research Procedures of Collaborative Jig Saw Project-Based Learning Model in Thermodynamics[15] 


\section{RESUlT AND DiscUSSION}

\section{A. Validity Test of CJPjBL Model in Thermodynamics}

Validity test was performed to obtain valid research products. The validity test was conducted using a questionnaire containing questions related to the model. Validation of CJPjBL model by 3 experts. In this case, the researcher gave questionnaires to the three validators mentioned above in order to validate the construction and the contents of the developed model. The results of validity test by the experts on CJPjBL model construction covered: model syntax, social system, reaction principle, support system, and instructional impact are valid with Aiken's V value of 0.863 . While the validity test results by the experts on the content of $\mathrm{CPjBL}$ model by the validator of the quality aspect of content and the quality of learning is valid with Aiken's V value of 0.840 . The value of Aiken's V on construction and model content by experts is above $>0.600$; CJPjBL model validation by experts to the construction and content of the model is "valid" to be used in thermodynamics.

\section{B. Practicality Test of CJPjBL Model Based on Teacher Response}

The practicality test of the CJPjBL model was based on whether the model can be carried out and done throughout the learning process and whether activities are carried out in accordance with the activities listed on the CJPjBL model in thermodynamics. Model practicality test was requested to 4 lecturers of thermodynamics course subjects. In terms of the quality of the content and purpose of the model, the results of teachers' response to the practicality test of CJPjBL model in thermodynamics can be seen in Table I.

TABLE I. Practical Test Results of Model CJPJBL Base on TEACHER RESPONSE

\begin{tabular}{|c|c|c|c|}
\hline No. & Aspects of Assessment & $\begin{array}{c}\text { The percentage } \\
\text { of assesment } \\
\text { (ave.) }\end{array}$ & Categori \\
\hline 1 & Usability & 82.00 & $\begin{array}{l}\text { Very } \\
\text { Practical }\end{array}$ \\
\hline 2 & Information Quality & 83.33 & $\begin{array}{l}\text { Very } \\
\text { Practical }\end{array}$ \\
\hline 3 & $\begin{array}{lr}\text { Interaction } & \text { or } \\
\text { Instructional } & \text { Process } \\
\text { Quality } & \\
\end{array}$ & 81.67 & $\begin{array}{l}\text { Very } \\
\text { Practical }\end{array}$ \\
\hline \multicolumn{2}{|r|}{ Average } & 82,33 & $\begin{array}{c}\text { Very } \\
\text { Practical }\end{array}$ \\
\hline
\end{tabular}

Based on the lecturers' assessment on usability, information quality, interaction or instructional process quality, an average value is 82.33 . From these values, it can be said that the CJPjBL model is very practical to be used in thermodynamics.

\section{Practicality Test of CJPjBL Model Based on Learner Response}

The CJPjBL model practice test was done through the learners' response. 29 students were given questionnaires containing questions related to the aspects of usability, information quality, and interaction or instructional process quality model. Practicality test results of students' response to the model CJPjBL in thermodynamics can be seen in Table II.
TABLE II. PPRACTICAL TEST OF CJPJBL MODEL BASE ON LEARNER RESPONSE

\begin{tabular}{|c|c|c|c|}
\hline No. & $\begin{array}{c}\text { Aspects of } \\
\text { Assessment }\end{array}$ & $\begin{array}{c}\text { The percentage } \\
\text { of assesment } \\
\text { (ave.) }\end{array}$ & Categori \\
\hline 1 & Usability & 81.25 & Very Practical \\
\hline 2 & Information Quality & 80,89 & Very Practical \\
\hline 3 & $\begin{array}{l}\text { Interaction or } \\
\text { Instructional Process } \\
\text { Quality }\end{array}$ & 80.68 & Very Practical \\
\hline \multicolumn{2}{|r|}{ Average } & 80,94 & Very Practical \\
\hline
\end{tabular}

The result of practical test of $\mathrm{CPjBL}$ model in thermodynamics based on student response on usability, information quality, interaction or instructional process quality is 80,94 in average. The scores showed that the $\mathrm{CPjBL}$ model is very practical to be used in thermodynamics.

\section{Effectiveness Test of the CJPjBL Model in Thermodynamics}

Before the t-test of the students' learning outcomes in the experimental class and control class, normality and homogeneity tests were performed on pretest and posttest results before being treated and after being put to shame. The result of normality test showed that the learning result of the experimental and control classes were normally distributed and homogeneous with Asymp.sig (2-tailed) value and significance for both classes $>0,05$. If both student learning outcomes have been distributed normally and homogeneously, then t-test can be done. The t-test is intended to see if there are differences in student learning outcomes in the experimental class with the learning model using CJPJBL and control class with conventional learning models, before and after learning thermodynamics.

1) T-Test To Pretest Results: T-test to the results of the students pretest at the beginning of the lecture was conducted to see if there are differences in student knowledge before learning thermodynamics. It is important to know the students' initial ability before getting treated using CJPJBL model.

TABLE III. T-TeST TO PRETEST OF THE EXPERIMENTAL AND CONTROL Classes

\begin{tabular}{|l|l|l|l|}
\hline No. & Aspects of Assessment & $\begin{array}{c}\text { The percentage } \\
\text { of assesment } \\
\text { (ave.) }\end{array}$ & Categori \\
\hline 1 & Usability & 82.00 & $\begin{array}{l}\text { Very } \\
\text { Practical }\end{array}$ \\
\hline 2 & Information Quality & 83.33 & $\begin{array}{l}\text { Very } \\
\text { Practical }\end{array}$ \\
\hline 3 & $\begin{array}{l}\text { Interaction or } \\
\text { Instructional Process } \\
\text { Quality }\end{array}$ & 81.67 & $\begin{array}{l}\text { Very } \\
\text { Practical }\end{array}$ \\
\hline \multicolumn{1}{|c|}{ Average } & $\mathbf{8 2 , 3 3}$ & $\begin{array}{c}\text { Very } \\
\text { Practical }\end{array}$ \\
\hline
\end{tabular}

Table III shows that the result of t-test on the pre-test value of students before any treatment using the CJPJBL model of students' learning ability on thermodynamics in both the experimental and control classes is almost the same in average. This can be seen from the significance of both classes of 0.176 and 0.182 which means the value is greater than 0.05 . 
2) T-Test To Posttest Results: The test at the end of the course (posttest) in thermodynamics was conducted to know the improvement of students' learning outcomes. Then, this posttest result was tested by t-test.

TABle IV. T-Test To Posttest of The Experimental and Control Classes

\begin{tabular}{|c|c|c|c|c|c|c|c|c|c|c|}
\hline \multicolumn{11}{|c|}{ Independent Samples Test } \\
\hline & & \multicolumn{2}{|c|}{$\begin{array}{c}\text { Levene's Test for } \\
\text { Equality of } \\
\text { Variances }\end{array}$} & \multicolumn{7}{|c|}{ t-test for Equality of Means } \\
\hline & & \multirow[t]{2}{*}{$\boldsymbol{F}$} & \multirow[t]{2}{*}{ Sig. } & \multirow{2}{*}{$t$} & \multirow[t]{2}{*}{$d f$} & \multirow{2}{*}{ Sig. (2-tailed) } & \multirow{2}{*}{$\begin{array}{c}\text { Mean } \\
\text { Difference }\end{array}$} & \multirow{2}{*}{$\begin{array}{l}\text { Std. Error } \\
\text { Difference }\end{array}$} & \multicolumn{2}{|c|}{$\begin{array}{c}\text { 95\% Confidence Interval of the } \\
\text { Difference }\end{array}$} \\
\hline & & & & & & & & & Lower & Upper \\
\hline \multirow{2}{*}{ Value } & $\begin{array}{l}\text { Equal variances } \\
\text { assumed }\end{array}$ & 5.334 & .028 & 1.416 & 54 & .176 & 1.94490 & 1.37699 & -.83218 & 4.68298 \\
\hline & $\begin{array}{l}\text { Equal variances not } \\
\text { assumed }\end{array}$ & & & 1.373 & 42.015 & .182 & 1.94490 & 1.42295 & -.93872 & 4.78951 \\
\hline \multicolumn{11}{|c|}{ Independent Samples Test } \\
\hline & & \multicolumn{2}{|c|}{$\begin{array}{c}\text { Levene's Test for } \\
\text { Equality of } \\
\text { Variances }\end{array}$} & \multicolumn{7}{|c|}{ t-test for Equality of Means } \\
\hline & & \multirow[t]{2}{*}{$\boldsymbol{F}$} & \multirow[t]{2}{*}{ Sig. } & \multirow[t]{2}{*}{$t$} & \multirow[t]{2}{*}{$d f$} & \multirow[t]{2}{*}{ Sig. (2-tailed) } & \multirow{2}{*}{$\begin{array}{c}\text { Mean } \\
\text { Difference }\end{array}$} & \multirow{2}{*}{$\begin{array}{l}\text { Std. Error } \\
\text { Difference }\end{array}$} & \multicolumn{2}{|c|}{$\begin{array}{c}\text { 95\% Confidence Interval of the } \\
\text { Difference }\end{array}$} \\
\hline & & & & & & & & & Lower & Upper \\
\hline \multirow{2}{*}{ Value } & $\begin{array}{l}\text { Equal variances } \\
\text { assumed }\end{array}$ & 1.468 & .258 & -10.768 & 52 & .000 & -13.25194 & 1.23495 & -15.73006 & -10.77383 \\
\hline & $\begin{array}{l}\text { Equal variances not } \\
\text { assumed }\end{array}$ & & & -10.560 & 45.665 & .000 & -13.25194 & 1.25614 & -15.78093 & -10.72296 \\
\hline
\end{tabular}

Based on the result of t-test on post-test result as shown in table 4:29 obtained the significance result of both classes was 0.000 which was smaller value than 0,05 . This means that both classes of control classes and experimental classes at the end of the course have different learning outcomes. It shows that there is a significant difference between the control class learning outcomes and the experimental class at the end of the lecture.

Then, it can be concluded that the experimental class learning result with treatment using $\mathrm{CPjBL}$ model is higher than the untreated class (using conventional learning model). Thus, the $\mathrm{CPjBL}$ model is more effective than the conventional model of thermodynamic learning in vocational education.

They took turns teaching their teammates about the subchapters they understood and each other listening intently. After that, the students discussed in the form of presentation in front of the class. It was intended to let the lecturers equate students' perceptions of thermodynamic teaching materials by holding discussions. The joy of this chase was impressed by the concept of collaborative learning. In collaborative learning, learners work together to improve their learning [17].

\section{E. The Improvement of Students' Learning Outcomes in Thermodynamics}

1) Students' Learning Outcomes of the Control Class: Improved student learning outcomes in both control and experimental classes can be seen through the acquisition of grades from students on a small test given at each lecture, from week 2 to week 15 . The number of questions on a small test in each lecture was 10 points each. The results of the small test given to the students at each lecture can be seen below.

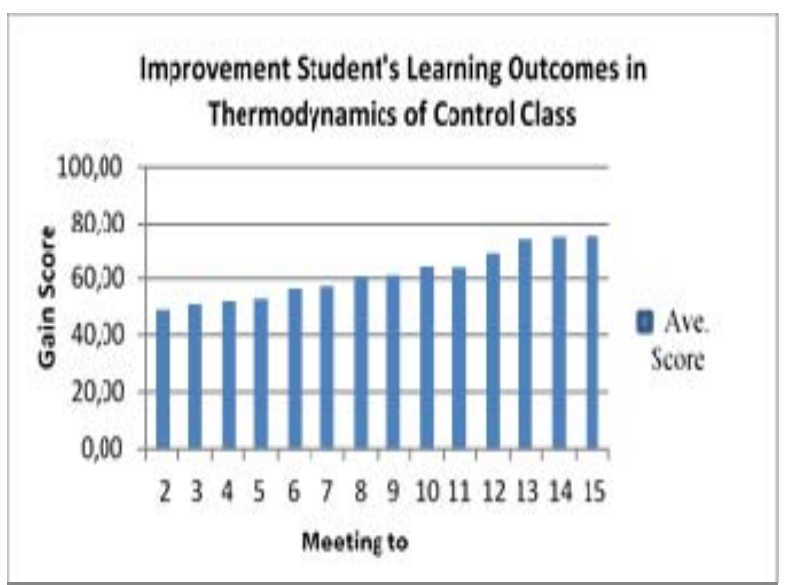

Fig. 2. Histogram of the Improvement of Students' Learning Outcomes of Control Class

Figure 3. is a histogram of improved student learning outcomes in the control class in thermodynamic learning using conventional learning model. From the histogram, it can be seen that student learning outcomes are lower, when compared to the learning outcomes in the experimental class using $\mathrm{CPjBL}$ model. It can be concluded that there was an improvement in student learning outcomes in control classes, from each lecture meeting from week 2 to week 15 , but not yet optimal when compared to the experimental model in the experimental class. 


\section{2) Student's Learning Outcomes of the Control Class}

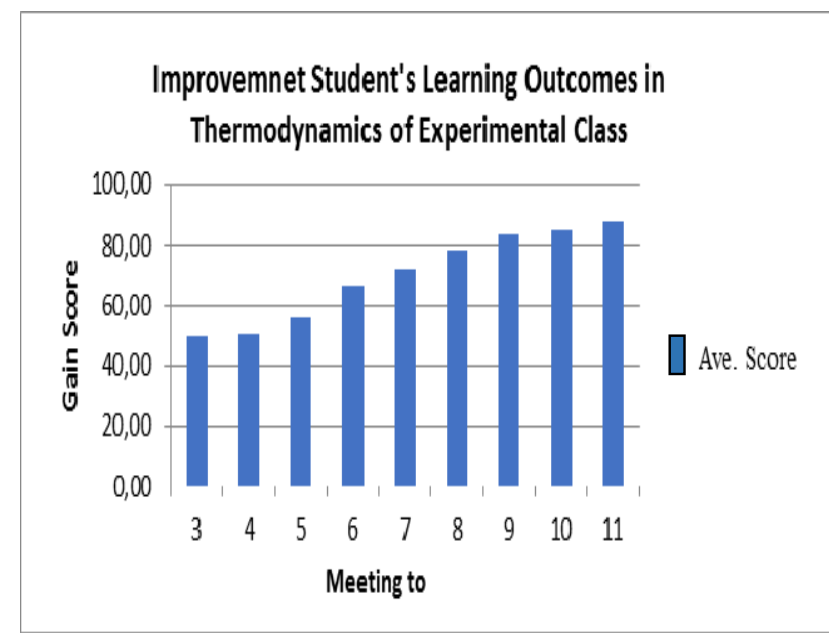

Fig. 3. Histogram of the Improvement of Students' Learning Outcomes of Experimental Class

From the summary of student learning outcomes, it can be concluded that the average learning outcomes of experimental class students improved significantly. In the 11 th week of lectures, the average student score was 88.28. When comparing the beginning of the lecture to the end of the lecture, there is a significant increase in value (gain score) in the category of very good.

3) The Comparison of Improved Students' Learning Outcomes of Experimental and Control Classes: The improvement of student learning outcomes was seen from the average value of learning at the beginning and at the end of the lecture for the experimental and the control classes. It was intended to compare student learning outcomes before and after being treated (experiment). For control class, at the beginning of the course, their average score was 48.8 and the experimental class was 49.31. At the end of the class, for the control class, the average score was 74.80 while for the experimental class was 88.28. The improved learning outcomes in initial and final learning in classroom and control classes can be illustrated in Figure 4.

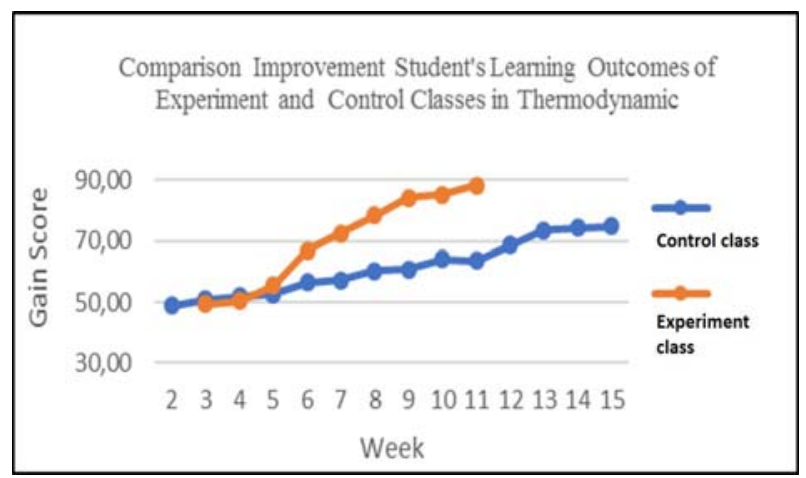

Fig. 4. Graph of the Comparison of Improved Students' Learning Outcomes Experiments and Control Classes

From figure 4 , it can be concluded that for the control class, the learning model using conventional model happened with the average increase of learning result (gain score) student of 26 points. As for the experimental class the obtained value was 38.97 points.

From this result, it can be proven that learning using CJPjBL model in thermodynamics in vocational education can improve student's learning outcomes, compared to control class using conventional learning method. The results of this study are in accordance with what has been described by [4] that learning model in education should be interactive and motivating students to participate actively. The use of CJPjBL model in this research makes students more motivated, able to cooperate, more creative and innovative. It is in accordance with [6] who stated that vocational education takes place when an individual or a group of individuals gets information, understanding, abilities, skills, appreciation, interests and/or attitudes, which enable him to start or continue a productive activity.

The use of CJPjBL model in thermodynamics' course can make students able to face new challenges and to find their roles as productive members of society. It is an effective tool for achieving social cohesion, integration and self-esteem [6].

This means that the use of CJPjBL model in thermodynamics' course strongly supports the concept and purpose of vocational education i.e: preparation of individuals for paid or unpaid employment, or for additional preparation for a career requirement.

\section{CONCLUSION}

The results showed that the CJPJBL model is valid, highly practical and effective in use in thermodynamic learning, with average Aiken's V average validity value by experts above 0.070 ; the level of practicality based on lecturer and student response were $83,67 \%$ and $81,67 \%$ which belonged to very practical category. Furthermore, CJPJBL model is also effective in improving student learning outcomes in thermodynamics. The result of t-test showed that there was a significant difference of student's learning result in experimental class using CJPJBL model with control class using conventional model in thermodynamic learning. The gain score for the experimental class was 38.97 points and the control class was 26 points. The final average score of student learning outcomes in the experimental class was 88.28 and the control class was 74.80 .

Further, CJPjBl model which has been applied in TVET so as to help students in improving their competence and facilitate them to enter the world of work. Besides, this CJPjBL model may be able to develop of students critical thinking, and having good morale [19].

Since the CJPJBL model is valid, practical, effective and improve student motivation, critical thinking used in thermodynamics, it was advisable for thermodynamics lecturers to use CJPJBL model in thermodynamics and other relevant subjects. 
In this occasion, we are especially grateful to the Dean of the Faculty of Engineering, Universitas Negeri Padang and Chairman of the Department of Mechanical Engineering, Faculty of Engineering, Universitas Negeri Padang who has facilitated the implementation of this research. We also express our gratitude to all those who are not mentioned one by one, who provide their assistance so that this research can be completed as expected. May God repay all your good deeds. May God bless you.

\section{REFERENCES}

[1] Undang-undang Republik Indonesia Nomor 20 Tahun 2003 Tentang Sistem Pendidikan Nasional. Internet available from http://www.geocities,com/frans_98/uu/uu_20_03.htm. Accesed on April 10th 2008.

[2] Notoatmodjo, Soekidjo. Pendidikan dan Perilaku Kesehatan. Jakarta. Rineka Cipta. 2003. h. 3.

[3] Miles Berry (2012) [ONLINE]: http://milesberry.net/ 2009/09/meaningful-learning-and-ict/

[4] Peraturan Pemerintah Nomor 32 Tahun 2013 Tentang Perubahan atas Peraturan Pemerintah Nomor 19 Tahun 2005 Tentang Standar Nasional Pendidikan.

[5] Evans, Rupert N, dan Edwin, Lewis H. 1978. Foundation of Vocational Education. Columbus. Ohio: Charles E. Merril Publishing Company.

[6] Byram, H.M. \& Wenrich, R.C. (1956). Vocational Education and Practical Arts in the Community School. New York: The Macmillan Company.

[7] Nizwardi Jalinus. 2014. "Pengembangan Model Pengembangan Model Pembelajaran Kompetensi Teknik Pemesinan Berbasis Project Based-Learning Pada Pendidikan Vokasi Dan Kejuruan di Sumatera Barat”. Laporan Penelitian Tim Pascasarjana.Padang. UNP Press.

[8] M Y A Hadi et al. 2015. "Application of Thinking Skills in Career: A Survey on Technical and Vocational Education Training (TVET)
Qualification Semi-Professional Job Duties". 2nd Global Conference on Business and Social Science-2015, GCBSS-2015, 17-18 September 2015, Bali, Indonesia.

[9] Calhoun, C. C., \& Finch, A. V. 1980. Vocational and Career Education: Concepts and Operation. Belmount California: Wads Wort Publishing Company.

[10] Arwizet K. 2017. "Collaborative Project-Based Learning: An Instructional Design Model In Thermodynamics On Technical Vocational Education And Training (TVET)". Prosiding. 4th UNP International Conference on Technical and Vocational Education and Training. Padang, November 9th - 11th, 2017.

[11] Cengel, Yunus A and Michael A. Boles. 2015. Thermodynamics: An Engineering Approach, 5th. New York. Mc-Graw-Hill.

[12] Ezekoka, G. K. 2015. Maximizing the Effect of Collaborative Learning Through ICT. Procedia- Social and Behavioral Sciences 176 (2015) 1005-1011.

[13] Dillebourg, P. 1999. What do you mean by "collaborative learning? In P. Dillenbourg (Ed), Collaborative-learning: Cognitive and Coputational Approaches (pp1-15). Oxford: Elsevier.

[14] Balve, P. and Albert, M. (2015). "Project based Learning in Production Engineering at the Heilbronn Learning Factory". Procedia CIRP. 32: 104-108.

[15] Branch, R.M. 2009. Instructional Design:The ADDIE Approach. New York: Springer USA.

[16] Thompson.1973. Foudation of Vocational Education: Social and Philosophical Concept. Michigan: Prentice-Hall.

[17] Ezekoka, G. K. 2015. Maximizing the Effect of Collaborative Learning Through ICT. Procedia- Social and Behavioral Sciences 176 (2015) 1005-1011.

[18] Balve, P. and Albert, M. (2015). Project based Learning in Production Engineering at the Heilbronn Learning Factory. Procedia CIRP. 32: 104-108.

[19] M. Laal. et al. 2013. Individual Accountability in Collaborative Learning. 